\title{
KEPUASAN PASIEN BPJS TERHADAP PELAYANAN KEPERAWATAN: STUDI KASUS DI RSUD SYEKH YUSUF KABUPATEN GOWA
}

\author{
A.Saputri Mulyana ${ }^{1)}$, Liliskarlina ${ }^{2)}$, Dian Ekawaty ${ }^{3)}$ \\ 1,2,3 Fakultas Kesehatan, Universitas Patria Artha \\ Email: saputrimulyana@patria-artha.ac.id
}

\begin{abstract}
Abstrak
Keperawatan sebagai bagian integral dari pelayanan kesehatan, merupakan implikasi atas tanggungjawab perawat dalam melayani kebutuhan pasien selama 24 jam. Kompleksitas pemenuhan kebutuhan dasar klien sebagai tujuan dari interaksi perawat terhadap klien menuntut perawat sebagai pemberi asuhan keperawatan dapat memaksimalkan profesionalitasnya, termasuk diantaranya kepada pasien pengguna BPJS Kesehatan. Studi ini dilakukan secara kualitatif dengan pendekatan fenomenologi untuk memahami makna pengalaman pasien pengguna BPJS terhadap pelayanan keperawatan di RS. Syekh Yusuf, Kabupaten Gowa. Proses pengumpulan data dilakukan melalui wawancara mendalam, telusur dokumen, dan observasi lapangan. Hasil penelitian mengidentifikasi 3 (tiga) tema, yaitu: Mengharapkan sikap perawat yang lebih caring; sikap caring perawat dapat membuat nyaman dan perasaan sembuh lebih cepat; dan Puas dengan biaya perawatan yang sesuai. Penelitian ini merekomendasikan pada penelitian selanjutnya dapat mengkaji cultural competence para perawat di Rumah Sakit. Dan kepada manajemen keperawatan di Rumah Sakit agar kiranya dapat melakukan pemberian cultural awareness workshop (pelatihan asuhan keperawatan peka budaya) untuk meningkatkan cultural competence para perawat.
\end{abstract}

\section{Kata kunci: BPJS Kesehatan; Caring; Kepuasan; Pelayanan Keperawatan}

\begin{abstract}
Nursing as an integral part of health services is an implication of nurses 'responsibility in serving patients' needs for 24 hours. The complexity of fulfilling the client's basic needs as the goal of nurse interaction with the client requires the nurse as the provider of nursing care to maximize their professionalism, including for the patients, user of BPJS Health. This study was conducted qualitatively with a phenomenological approach to understand the meaning of the experience of patients with BPJS on nursing services in Syekh Yusuf Hospital, Gowa Regency. The process of collecting data is done through in-depth interviews, document searches, and field observations. The results of this study was identified by 3 (three) themes, namely: Expect more caring nurse attitudes; caring attitude of nurses can make comfort and feeling heal faster; and Satisfied with the appropriate maintenance costs. This study recommends that further research can examine the cultural competence of nurses in hospitals. And to the nursing management at the Hospital, they can conduct a cultural awareness workshop to increase the cultural competence of nurses.
\end{abstract}

\section{Keywords: Caring; Nursing Care; Satisfaction ; Social Insurance Administration Organization}

\section{PENDAHULUAN}

Keperawatan sebagai bagian integral dari pelayanan kesehatan, memiliki peranan yang cukup vital terhadap penerapan perilaku sehat. Keperawatan juga berperan dalam mengarahkan perilaku sakit klien agar dapat melakukan tindakan positif sebagai upaya untuk meningkatkan derajat kesehatannya.
Peranan penting ini merupakan implikasi atas tanggungjawab perawat dalam melayani kebutuhan pasien selama 24 jam dan sebagai tenaga kesehatan dengan proporsi terbesar. Berdasarkan data dari Kementerian Kesehatan RI (2015), perawat merupakan tenaga kesehatan dengan proporsi terbesar di Indonesia pada tahun 2014, yakni mencapai 237.181 orang $(41 \%)$, diikuti oleh bidan yaitu 124.948 orang (22\%), dokter spesialis 
mencapai 46.994 (8\%), dokter umum mencapai 40.787 orang (7\%), dan sisanya adalah tenaga kesehatan lain seperti: farmasi $5 \%$, keteknisian medis 5\%, kesehatan masyarakat $4 \%$, gizi $3 \%$, dokter gigi $2 \%$, kesehatan lingkungan $2 \%$, keterapian fisik $1 \%)$.

Untuk mengoptimalkan peran dan fungsi tersebut, perawat harus senantiasa berfokus pada falsafah dasar keperawatan, yaitu caring. Beberapa hasil studi mengemukakan bahwa perilaku caring pada profesi keperawatan merupakan prinsip utama sebagai sebuah ilmu yang menjalin hubungan dengan manusia (Paldanius \& Maatta, 2011; Watson, 2009). Sebagaimana yang dinyatakan oleh Eggenberger et al. (2012), perawat merupakan sebuah profesi sebagai pusat terjalinnya caring. Hal ini akan memengaruhi kualitas pelayanan yang diberikan kepada klien (Andre, Sjovold, Rannestad, \& Ringdal, 2014). Kesadaran inilah yang menjadikan perawat memandang manusia secara utuh dalam memberikan pelayanan keperawatan. Caring of nursing merupakan sebuah upaya peningkatan mutu pelayanan keperawatan dan keselamatan pasien. Perawat telah gagal dalam menjalankan tugasnya jika tidak dapat caring terhadap pasien (Nursalam, 2014; Stein \& Parbury, 2006).

Perilaku caring dalam keperawatan dimanifestasikan sebagai sebuah sikap yang lahir dari lubuk hati yang paling dalam, bagian dari etik keperawatan, dan sebagai bentuk profesionalitas perawat dengan fokus pada kebutuhan pasien. Perilaku caring perawat pada tindakan keperawatan akan memberikan kepuasan kepada pasien. Pernyataan ini diperkuat oleh hasil studi kuantitatif yang dilakukan oleh Gurusinga, Sulistyaningsih, dan Tarigan (2013) dan Watson (2009). Pemaparan Hariyati (2014); Marquis dan Huston (2012); Nursalam (2015) menekankan bahwa kepuasan klien sebagai konsumen merupakan salah satu indikator mutu asuhan keperawatan. Kompleksitas pemenuhan kebutuhan dasar klien sebagai tujuan dari interaksi perawat-klien menuntut perawat sebagai pemberi asuhan keperawatan dapat memaksimalkan profesionalitasnya, salah satunya melalui penerapan fungsi manajemen.

Manajemen keperawatan tentu memegang kendali dalam memainkan pelayanan keperawatan. Hal ini dapat dilakukan oleh manajer keperawatan dengan menjalankan fungsi-fungsi manajerial melalui perencanaan, pengorganisasian, pengaturan tenaga (staffing), pengarahan dan pengawasan, serta pengendalian (controlling). Marquis dan Huston (2012) menekankan bahwa upaya kendali mutu merupakan bagian dari fungsi controlling dalam sistem manajemen keperawatan. Hal ini dapat dilakukan melalui pemberian asuhan keperawatan yang berfokus pada kepuasan klien sebagai salah satu indikator mutu pelayanan keperawatan (Hariyati, 2014; Nursalam, 2015; Sitorus \& Panjaitan, 2011).

Rumah Sakit Umum Daerah (RSUD) Syekh Yusuf merupakan rumah sakit negeri kelas B yang di Kabupaten Gowa, Provinsi Sulawesi Selatan. Rumah sakit ini telah meraih akreditasi 5 (lima) layanan, berlanjut pada akreditasi penuh Rumah Sakit Umum (RSU) 12 layanan pada tahun 2012, dan tahun 2013 berhasil meraih Pelayan Publik Terbaik kategori Bidang Kesehatan. Jumlah kunjungan rata-rata dalam setahun mencapai 116.437 pasien, dengan BOR (Bed Occupancy Ratio) mencapai 75,34\%, dan ALOS (Average Length of Stay) adalah 3 (tiga) hari. Rumah Sakit yang telah meraih piagam penghargaan tingkat madya Citra Pelayanan Prima pada tahun 2010 ini memiliki 215 tempat tidur, 49 dokter (26 diantaranya adalah dokter spesialis), 218 perawat, dan 95 orang profesi tenaga kesehatan lainnya (RSUD Syech Yusup Gowa, 2015; SarRil, 2015).

Beberapa hasil penelitian menggambarkan mutu pelayanan di RSUD Syekh Yusuf, Kabupaten Gowa. Rahman (2015) dalam studinya menyatakan bahwa mutu pelayanan kesehatan terhadap pasien BPJS di instalasi rawat jalan RSUD Syekh Yusuf sudah cukup baik. Hal ini ditinjau dari kompetensi teknis, akses, kesinambungan, efektivitas, efisiensi, 
keamanan, kenyamanan, informasi, ketepatan waktu, dan hubungan antar manusia. Namun, studi kuantitatif yang dilakukan oleh Hafid (2014) mendapatkan hasil yang berbeda. Hasilnya menunjukkan adanya hubungan antara kinerja perawat dengan tingkat kepuasan pasien di RSUD Syekh Yusuf, dengan $P$-value sebesar 0,008 . Hasil yang diperoleh adalah $70 \%$ (21 responden) menunjukkan kinerja perawat kurang dan $70 \%$ (21 responden) menunjukkan ketidakpuasan terhadap pelayanan keperawatan. Adapula data yang ditunjukkan oleh Safitri, Maidin, Arifah (2014) bahwa terjadi penurunan kepuasan pasien terhadap pelayanan keperawatan di RSUD Syekh Yusuf dari tahun 2012, dan nilai terendah berada pada tahun 2014 yang mencapai $77,5 \%$. Sementara menurut Kepmenkes No. 129 tahun 2008 tentang standard pelayanan minimum rumah sakit menyatakan bahwa angka kepuasan klien di instalasi rawat inap adalah $\geq 90 \%$ dan di IGD adalah $\geq 70 \%$.

Selain itu, juga ditemukan perbedaan kepuasan pasien JKN (Jaminan Kesehatan Nasional) dan pasien umum dalam hal ketersediaan informasi, kompetensi, perhatian, dan keterampilan perawat di rawat inap RSUD Syekh Yusuf. Suaib, Indar, dan Jafar (2012) juga menunjukkan bahwa variabel yang paling berpengaruh terhadap kepuasan pasien di RSUD Syekh Yusuf adalah pelayanan perawat, baik pada pasien umum maupun pasien Asuransi/Jamkesmas, dengan $P$-value sebesar 0,004. Pelayanan keperawatan yang dimaksud adalah dalam hal kemampuan perawat dalam memberikan penjelasan kepada pasien berkaitan dengan tindakan medik, kemampuan memberikan rasa aman, dan sopan santun terhadap pelayanan yang diberikan kepada pasien. Pada studi lain, Fatmawati (2014) menunjukkan tingkat pengetahuan perawat terhadap pendokumentasian asuhan keperawatan sebesar $54.4 \%$ dari 79 orang perawat dan kelengkapan pendokumentasian memiliki nilai rata-rata $54.8 \%$ dari 120 dokumentasi asuhan keperawatan.

Sumber lain menyampaikan tentang gambaran pelayanan di RSUD Syekh Yusuf. Nurmin (2015) menceritakan tentang penolakan sejumlah pasien oleh perawat di IGD RSUD Syekh Yusuf Gowa, pada 29 November 2015 lalu. Peristiwa ini membuat sejumlah keluarga pasien memaksa dan terjadi adu mulut akibat penolakan pemeriksaan pasien karena alasan sedang terjadi pemadaman listrik dan tidak terdapat ruang kosong. Pada 22 Juli 2015 lalu, juga diporkan tentang kasus bayi tertukar yang terjadi di ruang perawatan anak RSUD Syekh Yusuf (Agus, 2015). Hasil wawancara melalui komunikasi pribadi yang dilakukan pada 17 februari 2016 kepada Ny. A juga mengeluhkan tentang kualitas pelayanan keperawatan yang perlu dibenahi. Ny. A adalah orang Makassar yang pernah menerima pelayanan keperawatan di RSUD Syekh Yusuf, Kabupaten Gowa.

Fenomena-fenomena tersebut kemudian melatarbelakangi peneliti untuk mengkaji lebih dalam bagaimana pengalaman pasien pengguna BPJS Kesehatan terhadap pelayanan keperawatan di RSUD. Syekh Yusuf Kabupaten Gowa. Setelah menafsirkan makna pengalaman orang Makassar menerima pelayanan keperawatan, diharapkan peneliti mendapatkan esensi dari pengalaman yang dideskripsikan tersebut. Oleh karena itu, gambaran pelayanan keperawatan tidak hanya dipaparkan secara kuantitatif saja, tapi juga menggali dan memahami apa yang ada di balik fenomena tersebut. Hal ini dilakukan sebagai sebuah upaya untuk meningkatkan mutu pelayanan keperawatan, terutama di RSUD Syekh Yusuf, Kabupaten Gowa.

Tujuan dari penelitian ini adalah mengetahui makna pengalaman pasien pengguna BPJS terhadap pelayanan keperawatan di RS. Syekh Yusuf, Kabupaten Gowa.

\section{METODE}

Penelitian ini diawali dengan membaca studi literatur yang berkaitan dengan judul penelitian yang kami usulkan. Selanjutnya diadakan studi lapangan serta pengambilan data sekunder dan data primer. Penelitian ini merupakan penelitian kualitatif dengan pendekatan fenomenologi untuk memahami makna pengalaman pasien 
pengguna BPJS di RSUD Syekh Yusuf, Kabupaten Gowa.

Partisipan dalam penelitian ini pasien pengguna BPJS yang dianggap relevan dalam memberikan informasi mengenai kepuasan pasien pengguna BPJS Kesehatan terhadap pelayanan keperawatan di RSUD Syekh Yusuf, Kabupaten Gowa. Dengan demikian, informasi dapat diperoleh secara akurat dan berdasarkan perspektif pelaku yang terlibat langsung.

Teknik pemilihan partisipan pada penelitian ini menggunakan metode purposive sampling yang didasarkan pada kebutuhan penelitian. Oleh karena itu, kriteria inklusi pada penelitian ini adalah:

a. Tercatat sebagai pasien di Rumah Sakit tempat penelitian paling lama dalam waktu 6 (enam) bulan terakhir.

b. Pengguna BPJS

c. Usia 20-50 tahun.

d. Memiliki kemampuan kognitif yang baik (tidak dalam kondisi sakit jiwa, sakit kronik, dan segala bentuk keterbatasan lainnya)

e. Bersedia menjadi responden

\section{Lokasi Penelitian}

Pengambilan data yang dibutuhkan dalam penelitian dilakukan di RSUD Syekh Yusuf Kabupaten Gowa.

\section{Model yang digunakan}

Pengumpulan data pada penelitian ini dilakukan melalui wawancara mendalam (indepth interview) kepada partisipan dan penelusuran dokumen. Metode wawancara yang digunakan dalam penelitian ini adalah metode wawancara semi terstruktur dengan menggunakan pertanyaan terbuka (openended questions), dengan menanyakan topik yang berada pada pedoman wawancara dan selanjutnya menindaklanjuti respon yang diberikan partisipan (Pope, Royen, \& Baker, 2013). Prinsip dalam proses wawancara ini adalah memfasilitasi partisipan untuk mengungkapkan pengalamannya, sehingga peneliti tidak mendominasi pembicaraan dan tetap menindaklanjuti respon yang ditunjukkan oleh partisipan dengan menanyakan kembali saat partisipan belum memahami inti pertanyaan dari peneliti. Proses wawancara pada penelitian ini akan dilakukan selama 45-60 menit dalam sekali pertemuan, atau disesuaikan dengan kemampuan dan persetujuan partisipan.

\section{Teknik Pengumpulan dan Analisis Data}

Teknik pengumpulan data terbagi menjadi 3 (tiga) fase, yaitu: orientasi, kerja, dan terminasi. Fase orientasi didahului dengan menanyakan kesiapan partisipan untuk memulai proses wawancara. Fase kerja dilakukan dengan mengajukan sebuah pertanyaan terbuka, yaitu: "Bagaimana pengalaman Bapak/Ibu/Saudara saat dirawat di RSUD. Syekh Yusuf Kabupaten Gowa? “, dan selanjutnya menggali informasi dengan mengacu pada pedoman wawancara. Sedangkan fase terminasi dilakukan dengan mengakhiri wawancara jika pertanyaanpertanyaan inti telah dijawab dan dikemukakan oleh partisipan.

Proses analisis data ini dilakukan secara sistematis untuk dapat memudahkan dalam merumuskan makna pengalaman pasien pengguna BPJS terhadap pelayanan keperawatan di RSUD. Syekh Yusuf Kabupaten Gowa melalui: koding, membuat kategori-kategori, membentuk sub tema, dan membentuk tema.

\section{HASIL DAN PEMBAHASAN}

\section{Latar belakang Partisipan}

Partisipan pada penelitian ini adalah Pasien pengguna BPJS Kesehatan di RSUD Syekh Yusuf Kabupaten Gowa, sebanyak 4 (empat) orang, sebagai representasi dari pendekatan fenomenologi yang digunakan pada penelitian ini melalui wawancara mendalam. Adapun karakteristik partisipan tersebut dapat dilihat melalui tabel berikut: 
Tabel 1 Latar belakang Partisipan

\begin{tabular}{|c|c|c|c|c|}
\hline Kategori & P1 & $\mathbf{P 2}$ & $\mathbf{P 3}$ & $\mathbf{P 4}$ \\
\hline No. Partisipan & 01 & 02 & 03 & 04 \\
\hline Umur & 24 tahun & 23 tahun & 34 tahun & 43 tahun \\
\hline Jenis Kelamin & Perempuan & Laki-laki & Laki-laki & Perempuan \\
\hline Agama & Islam & Islam & Islam & Islam \\
\hline $\begin{array}{l}\text { Pendidikan } \\
\text { Terakhir }\end{array}$ & SMA & S1 & SMA & SMA \\
\hline Pekerjaan & Mahasiswa & Tidak bekerja & $\begin{array}{l}\text { PNS di Kantor } \\
\text { Bupati }\end{array}$ & IRT \\
\hline Status pernikahan & Belum menikah & Belum menikah & Sudah menikah & Sudah menikah \\
\hline Diagnosa medis & $\begin{array}{l}\text { Post op. Tu. } \\
\text { Mammae }\end{array}$ & DBD & Thypoid & Tu. Ovarium \\
\hline Jumlah hari rawat & 3 hari & 7 hari & 4 hari & 4 hari \\
\hline Ruang Perawatan & IV & VII (Tulip lantai 3) & $\begin{array}{l}\text { VII (Tulip lantai } \\
\text { 2) }\end{array}$ & III \\
\hline Asuransi Kesehatan & BPJS Kelas 1 & BPJS Kelas 1 & BPJS Kelas 2 & $\begin{array}{l}\text { KIS (Kartu Indonesia } \\
\text { Sehat) Kelas } 3\end{array}$ \\
\hline
\end{tabular}

Tabel 1 menggambarkan tentang latarbelakang partisipan bahwa semua partisipan berada pada usia yang berbeda, dengan rentang 23-43 tahun. Terdapat 3 (tiga) partisipan dengan latar belakang pendidikan SMA dan seorang lainnya adalah sarjana (S1). Satu orang partisipan bekerja sebagai PNS (Pegawai Negeri Sipil) sementara tiga orang lainnya adalah tidak bekerja. Dua diantaranya belum menikah. Latar belakang penyakit keempat partisipan terlihat bahwa 2 orang adalah pasien bedah dan 2 orang pasien interna. Lama rawat mulai dari 3 hingga 7 hari. Semua partisipan dirawat pada ruang perawatan yang berbeda. Ada yang dirawat di ruang perawatan IV dengan menggunakan BPJS kelas 1, ada yang di ruang perawatan VII (Tulip lantai 3) dengan menggunakan BPJS kelas 1, ada yang di ruang perawatan VII (Tulip lantai 2) dengan menggunakan BPJS kelas 2, dan ada pula di ruang perawatan III dengan menggunakan KIS (Kartu Indonesia Sehat). Partisipan yang dirawat dengan menggunakan BPJS kelas 1 pada partisipan ini adalah partisipan pengguna BPJS umum (non PNS), yang sebelumnya pernah dirawat di ruang VVIP pada rumah sakit yang sama.

\section{Analisis Tematik}

Hasil penelitian mengidentifikasi 3 (tiga) tema, yaitu: Mengharapkan sikap perawat yang lebih caring; senang dengan kinerja perawat; dan faktor accessibility tidak begitu signifikan memengaruhi kepuasan pasien.

Perilaku caring pada penelitian ini terbagi menjadi 4 kategori, yaitu: berharap perawat dapat peduli kebutuhan dan kondisi pasien, berharap perawat dapat menjaga kenyamanan pasien, berharap perawat dapat menghargai pasien, dan berharap perawat dapat lebih komunikatif.

Peduli terhadap kebutuhan dan kondisi pasien, merupakan harapan dari 3 (tiga) orang partisipan kepada perawat setelah menerima pelayanan keperawatan di rumah sakit. Selama dirawat, ketiga partisipan pernah mengeluhkan ketidakpedulian perawat atas kondisi dirinya. Hal ini sebagaimana terungkap pada kutipan pernyataan: "Kalau umpamanya sudah $k i$ ' dioperasi toh, mannya perawat yang angkat $k i$ turun ke tempat tidurnya. Kaya' itu saya kemarin,, saya ji yang bergerak" (P1).Harapan serupa juga diungkapkan oleh partisipan ketiga: "Kalau pagi kan kadang agak baikan, siang lagi drop.Demam itu kan tiba-tiba biasa muncul, maunya dicek rutin" (P3). Sementara partisipan kedua menyampaikan keluhannya dengan nada tegas tentang perawat yang jarang masuk ke 
kamar pasien, kecuali untuk melakukan pemberian obat. Hal ini sebagaimana diungkapkan pada pernyataan: "Nda' pernah masuk, yang pas ji mau kasih pindah infus, yang mau didonor" (P2).

Keinginan terpenting lainnya diungkapkan dari seorang partisipan agar perawat dapat senantiasa menjaga kenyamanan pasien saat pemberian tindakan keperawatan. Pernyataan ini dapat dilihat pada kutipan berikut: "Maksudnya pelanpelan, begitu. Kalo misalnya diperhatikan juga kondisinya pasiennya. Kalo misalnya pasien masih merasa kesakitan, ya ditahan dulu ... Kan kalo disuntik kalo dia baik hati kan dilihat ekspresinya, apa dia kesakitan atau baik-baik saja" (P2). Pernyataan ini secara tersirat menunjukkan harapan orang Makassar agar perawat dapat menjaga kenyamanan pasien saat pemberian tindakan keperawatan. Melihat ekspresi pasien saat pemberian tindakan keperawatan dianggap sebagai salah satu indikator untuk dapat melihat kenyamanan pasien.

Selain itu, kurang menjaga privasi pasien pada saat diperiksa menunjukkan ketidaknyamanan pasien. Sebagaimana kutipan pernyataan berikut: "waktu diperiksa, seng cowok di dalam, malu-malu ki', ka ada ki di situ. Pas mau digunting anu nya toh, jahitannya, yang mau mi dilepas maksudku, ada itu, maluka" (P1). Observasi yang dilakukan pada tanggal $24 \mathrm{Mei}$ 2016 di ruang perawatan IV kamar IIIc dapat memperkuat pernyataan ini. Pada saat itu, terlihat bahwa saat proses perawatan luka berlangsung, seluruh orang yang ada di kamar bangsal itu dapat melihat dengan bebas. Tindakan perawatan luka tersebut dilakukan tanpa ada tirai pembatas di sekeliling pasien. Orang yang melintas di luar kamar bahkan dapat melihat tindakan tersebut, karena pintu kamar terbuka lebar.

Selain menghadirkan kenyamanan pasien, bentuk perilaku lainnya yang diharapkan terhadap perawat adalah sikap untuk lebih memanusiakan pasien. Harapan ini muncul saat partisipan merasa kurang dihargai oleh perawat pada saat sakit. Pernyataan ini terungkap dari kutipan:"Lebih belajar tentang bagaimana memperlakukan pasien. Maksudnya kan kita' juga orang Makassar, maksudnya rasa saling menghargai begitu"(P2).Partisipan juga mengeluhkan kelalaian mahasiswa saat memberikan obat. Hal ini diungkapkan sebagai bentuk kekecewaannya saat menerima pelayanan di rumah sakit. Ungkapan ini dapat dilihat dari pernyataan berikut: "Cuek ji, ketawaketawa ji, langsung ji saja juga pergi, nda' ada minta maaf apa, karena lalai.” (P2).

Harapan lain yang diungkapkan oleh 3 (tiga) orang partisipan terhadap perawat adalah bersikap lebih komunikatif. Hal ini disampaikan agar hubungan perawat dan pasien dapat terjalin dengan baik. Pernyataan ini diungkapkan sebagaimana kutipan berikut:"Perawat harusnya kan lebih dekat dengan masyarakat ... Setidaknya kalo masuk. Biar maksudnya kesannya lebih akrab begitu sama pasien" (P2). Sikap komunikatif ini dapat pula termanifestasikan melalui keramahan perawat saat pemberian asuhan keperawatan kepada pasien. Sebagaimana diungkapkan oleh partisipan ketiga, bahwa sikap ini dapat dilakukan dengan mengajak ngobrol kepada klien atau menanyakan keluhan pasien. Pernyataan ini dapat digambarkan pada kutipan: "Iye kayak yang murah senyum, ajak ngobrol.. Kan bisa di tunggu itu obat sambil ngobrol atau apa tanya-tanya keluhan lain apakah, ramahlah begitu"(P3).

Penelitian ini mengindikasikan keramahan sebagai sebuah keakraban yang dijalin oleh perawat kepada pasien. Beberapa orang Makassar yang pernah menerima pelayanan keperawatan menyatakan bahwa sikap ramah yang diharapkan terhadap perawat adalah kemampuan berbasa-basi kepada pasien dan keluarga, murah senyum, dan dapat mengajak cerita. Akan tetapi, yang perlu diperhatikan adalah tetap senantiasa menjaga etika dan kesopanan pada kondisi itu. Efek dari keramahan perawat ini dianggap dapat membuat perasaan cepat sembuh bagi pasien.

Tema kedua: Sikap caring perawat dapat membuat nyaman dan perasaan sembuh lebih cepat, teridentifikasi dari 2 (dua) kategori, yaitu merasa nyaman dirawat dan merasa cepat 
sembuh.

Sikap ramah yang ditunjukkan oleh perawat pada saat memberikan pelayanan keperawatan dianggap dapat memberikan rasa nyaman pada pasien saat dirawat. Hal ini sebagaimana diungkap oleh partisipan: "Kita' juga merasa diterima dengan baik kalo pihak-pihak yang menerimanya ramah. Kita' bisa lebih nyaman"(P2). Selain itu, sikap perawat yang ramah dan komunikatif, menjadikan partisipan merasa nyaman menjalani perawatan di Rumah Sakit. Seperti yang dikutip pada pernyataan berikut ini: "Suka' ji, karena dia tanya keadaanku. Mau ji dia tau keadaan penyakitku Enak kalo misalkan natanya ki. Maksudnya kaya ' peduliki, bilang baik ki ini" (P1). Perasaan yang sama juga diungkapkan oleh partisipan ke4 yang merasa senang jika dirawat oleh perawat yang ramah: "Senang karena perawatnya baikbaik. Pasti kita pasiennya merasa nyaman $k i$ ' dirawat di sini toh kalo begitu perawat. Ramahramah." (P4)

Selain itu, salah seorang dari partisipan juga bahkan merasa lebih cepat sembuh jika perawat bersikap ramah saat pemberian pelayanan keperawatan. Ungkapan ini dapat tergambarkan pada pernyataan berikut: "Cepat ka sembuh kaya'nya, karena suka bercanda”(P4).

Tema ketiga: puas dengan biaya perawatan yang sesuai, teridentifikasi dari 2 (dua) kategori, yaitu: Merasa pelayanan lebih baik dari sebelumnya dan Puas dengan biaya perawatan yang sesuai.

Dua orang partisipan merasa bahwa pelayanan di Rumah Sakit ini lebih baik dari sebelumnya. Seorang partisipan mengungkapkan bahwa pelayanan di IGD saat ini lebih bagus dari tahun lalu. Hal ini tergambar dalam ungkapan partisipan berikut: "Kita' kalo masuk di IGD dulu itu, nda' langsung diinfus ... Padahal kita' kan kalo masuk IGD, harusnya pertolongan pertamanya di IGD yang diinfus. Tapi dulu nda, terlalu cepat orang diinfus ... Saya bandingkan lebih bagus dari tahun lalu“ (P2).

Biaya perawatan yang harus dibayar sebanding kualitas pelayanan yang diperoleh, memberikan kepuasan partisipan saat dirawat. Hal ini sebagaimana terungkap pada pernyataan:"Trus selisih pembayarannya juga terjangkau ji. Maksudnya cocok, pas ji begitu. Masalah selisihnya dengan pelayanan yang didapat. Maksudnya sesuailah. Pas ji antara pelayanan yang didapat dengan pembayarannya"( $\mathrm{P} 2)$.

\section{Pembahasan}

Penelitian ini mengidentifikasi bahwa perilaku caring dan komunikatif perawat menjadi harapan pasien dalam menerima pelayanan keperawatan. Bentuk perilaku caring yang diharapkan adalah kepedulian perawat terhadap kebutuhan dan kondisi pasien. Bentuk kepedulian ini secara sederhana dapat dilakukan dengan melibatkan diri pada proses mobilisasi pasien, terutama setelah menjalani operasi.

Seorang responden yang baru saja menjalani operasi $\mathrm{Ca}$. Mammae menyatakan ketidakberdayaannya sebagai orang sakit pada saat dirawat. Hal ini memicu lahirnya keinginan agar perawat dapat lebih peduli terhadap kondisi dan kebutuhan pasien. Keterlibatan perawat saat proses mobilisasi pasien setelah operasi cukup dibutuhkan oleh pasien. Tidak hanya senang karena merasa diperhatikan, tapi juga karena pasien butuh diarahkan. Ketidakberdayaan pasien pada saat sakit melahirkan ketakutan untuk melakukan hal-hal yang dapat memperburuk kondisinya. Hal ini membuat tingkat ketergantungan pasien meningkat, sehingga merasa perlu untuk mendapat arahan dari perawat.

Pada teori human caring Watson, Cara (2009) menjelaskan tentang hubungan teraupetik yang perlu dijalin antara perawat dengan pasien. Pada teori ini, transpersonal caring yang dilakukan oleh perawat kepada pasien merupakan modal penting untuk memberikan rasa nyaman kepada pasien, yang akan membantu meredakan/mengurangi rasa nyeri, stress, dan penderitaan yang dirasakan, serta berperan dalam proses kesembuhan pasien. Pada pendapat yang sedikit berbeda, Tscudin (2007) menyatakan bahwa perawat tidak dapat membuat pasien menjadi berkembang (grow up). Akan tetapi, perawat dapat membantu mereka dalam mengenal dan memahami penyakitnya, serta dapat mengatasinya dengan baik.

Salah satu terapi non farmakologis yang dapat 
dilakukan oleh perawat dalam mengatasi stres dan gangguan fungsi psikologis pada klien adalah melalui Spiritual Care, baik kepada pasien secara individu maupun kepada keluarga. Pada sebuah studi, terapi ini dibuktikan sangat berpengaruh dalam menurunkan tingkat kecemasan pada keluarga penderita kanker di YKAKI Makassar (Mulyana, Tanrewali, Muhlis, 2018). Tindakan ini merupakan salah satu manifestasi dari caring perawat kepada klien.

Hasil obervasi menunjukkan seorang perawat laki-laki datang menemui pasien di kamarnya. Perawat itu kemudian menyapa pasien dan menanyakan kondisi yang baru saja telah diberikan perawatan luka. Nampak bahwa percakapan yang sedang berlangsung itu terjalin begitu akrab. Perawat itu berbicara dengan menggunakan bahasa Makassar, kemudian direspon dengan sangat terbuka oleh pasien dan keluarganya. Ekspresi senang dapat terpancar dari raut wajah pasien dan keluarga itu melalui senyum lepas yang dipasang diwajahnya. Kondisi yang berbeda diperoleh saat melakukan observasi di ruang yang sama dilakukan pada hari itu juga. Hasil observasi memperlihatkan seorang pasien yang baru saja selesai dilakukan operasi, kemudian diantar oleh mahasiswa ke dalam kamarnya dengan menggunakan brankar. Setelah pasien dipindahkan ke bed, kelima mahasiswa dan perawat laki-laki yang mengantarnya langsung pergi meninggalkan ruangan. Sementara posisi pasien diperbaiki oleh 2 dari 3 orang kerabat yang berpakaian biasa.

Ungkapan pasien terhadap ketidakpedulian perawat saat proses mobilisasi pasca operasi menimbulkan sebuah harapan melalui keluhan yang disampaikan. Pada kondisi yang berbeda, hasil penelitian ini juga menunjukkan adanya keluhan dari pasien terhadap perawat yang hanya masuk menemui pasien untuk memberikan obat, setelah itu keluar meninggalkan pasien tanpa basa-basi. Sementara, pasien mengharapkan keramahan perawat dengan mengajaknya bercerita ringan saat pemberian tindakan. Kondisi ini dianggap dapat menyebabkan munculnya rasa nyaman pada pasien saat dirawat. Selain merasa diperhatikan, dipedulikan, pasien juga merasa dihargai dan dianggap bahwa dirinya dapat diterima oleh petugas kesehatan di rumah sakit.

Fenomena ini menggambarkan salah satu konsep nilai yang diyakini oleh orang Makassar (masyarakat lokal), yaitu tentang harga diri (dignity). Meskipun dalam wujud sederhana, konsep dari nilai siri' ini juga berdampak pada saat sakit. Hasil penelitian ini menunjukkan bahwa keramahan perawat merupakan bagian dari bentuk menghargai pasien di rumah sakit. Ketidakberdayaannya sebagai orang sakit, menjadi alasan agar perawat dapat memperlakukan pasien dengan baik. Hasil penelitian ini sejalan dengan beberapa studi sebelumnya bahwa perilaku caring dapat menjadi indikator dari sikap perawat yang menunjukkan kualitas dalam sebuah pelayanan keperawatan. Olehnya itu, sikap ini dapat memengaruhi munculnya kepuasan pasien terhadap pelayanan keperawatan.

Penelitian ini juga mengidentifikasi pengaruh sikap (attitude) perawat terhadap kepuasan pasien saat menjalankan pelayanan keperawatan. Attitudes dan behavior dianggap ikut meningkatkan penilaian kinerja terhadap perawat (Sahertian, 2015; Wangge, 2013). Studi ini menunjukkan bahwa sikap ramah, peduli, dan komunikatif merupakan harapan orang pasien terhadap sikap perawat saat pemberian pelayanan keperawatan. Sikap ini dirasakan dapat memengaruhi kepuasan pasien selama menerima perawatan. Hasil penelitian ini memperkuat studi sebelumnya. Raman (2015) telah memberikan gambaran mutu pelayanan keperawatan di RSUD Syekh Yusuf, Kabupaten Gowa yang menunjukkan kurangnya kinerja perawat dengan tingkat ketidakpuasan mencapai 70\%. Studi kualitatif dari Liliskarlina dan Ekawaty (2018) menunjukkan bahwa kepuasan pasien pengguna BPJS dilihat dari kepuasan terhadap perawatan di RS mencakup aspek pelayanan, SDM, dan biaya.

Berbeda dengan kinerja dan sikap perawat yang dapat menurunkan angka kepuasan pasien, kesesuaian selisih biaya perawatan dengan pelayanan yang didapatkan dapat memuaskan pasien saat dirawat. Pernyataan ini diungkapkan oleh salah satu partisipan pengguna asuransi BPJS umum. Senada dengan studi yang dilakukan oleh Surianti (2015) bahwa jaminan yang cukup dapat melahirkan kepuasan pasien selama dirawat. Pada penelitian ini, tidak ada keluhan tentang biaya perawatan yang sulit dijangkau selama dirawat. Selain karena selisih 
biaya perawatan yang dianggap masih dapat dijangkau bagi pasien pengguna BPJS, penggunaan asuransi kesehatan bagi masyarakat miskin melalui program KIS (Kartu Indonesia Sehat), dianggap cukup membantu dalam menerima pelayanan kesehatan di Rumah Sakit. Tingginya biaya perawatan dapat menjadi salah satu sumber keluhan terhadap pelayanan kesehatan (Muninjaya, 2004). Berbeda dengan hasil penelitian ini, studi yang dilakukan oleh Ribeiro (2015) menunjukkan bahwa variabel harga tidak signifikan memengaruhi kepuasan pasien.

Studi tersebut juga sejalan dengan survey bidang keperawatan di RSUD Syekh Yusuf pada periode Januari-Juni 2015, bahwa angka kepuasan pasien di ruang perawatan interna mencapai $45,2 \%$. Jika merujuk pada standard kepuasan di RSUD Syekh Yusuf, hasil ini jauh di bawah indikator keberhasilan. Standard tersebut menunjukkan bahwa indikator keberhasilan kepuasan jika berada pada kategori 80-100, kategori 61-79 cukup puas, dan $\leq 60$ kepuasan kurang. Kesimpulan yang sama dapat terlihat pada Kepmenkes no. 129 tahun 2008 tentang standard pelayanan minimal rumah sakit. Hasil penelitian tersebut belum memenuhi standard kepuasan klien di ruang rawat inap, yaitu $\geq 90 \%$.

Berbeda dengan kinerja dan sikap perawat yang dapat menurunkan angka kepuasan pasien, kesesuaian selisih biaya perawatan dengan pelayanan yang didapatkan dapat memuaskan pasien saat dirawat. Pernyataan ini diungkapkan oleh salah satu partisipan pengguna asuransi BPJS umum. Senada dengan studi yang dilakukan oleh Surianti (2015) bahwa jaminan yang cukup dapat melahirkan kepuasan pasien selama dirawat. Pada penelitian ini, tidak ada keluhan tentang biaya perawatan yang sulit dijangkau selama dirawat. Selain karena selisih biaya perawatan yang dianggap masih dapat dijangkau bagi pasien pengguna BPJS, penggunaan asuransi kesehatan bagi masyarakat miskin melalui program KIS (Kartu Indonesia Sehat), dianggap cukup membantu dalam menerima pelayanan kesehatan di Rumah Sakit. Tingginya biaya perawatan dapat menjadi salah satu sumber keluhan terhadap pelayanan kesehatan (Muninjaya, 2004). Berbeda dengan hasil penelitian ini, studi yang dilakukan oleh Ribeiro (2015) menunjukkan bahwa variabel harga tidak signifikan memengaruhi kepuasan pasien.

Studi yang dilakukan oleh Farianita (2016) menyatakan bahwa kepuasan peserta BPJS terhadap pelayanan yang didapatkan dapat diidentifikasi melalui 4 (empat) faktor. Keempat faktor tersebut adalah persepsi prosedur pelayanan, persepsi pelayanan sumber daya manusia, persepsi pelayanan obat, dan persepsi fasilitas. Sementara Rahman (2015) memberikan gambaran tentang mutu pelayanan kesehatan peserta BPJS di Instalasi Rawat Jalan RSUD Syekh Yusuf, Kabupaten Gowa.

\section{KESIMPULAN}

Sikap caring dan komunikatif perawat merupakan harapan pasien pengguna BPJS Kesehatan yang dapat membuatnya merasa nyaman dan perasaan sembuh lebih cepat. Pasien juga merasa puas dengan biaya perawatan yang dianggap sesuai saat dirawat di RS. Syekh Yusuf. Kabupaten Gowa.

\section{REFERENSI}

1. Agus, M. (22 Juli 2015). Bayi tertukar, pihak rumah sakit syekh yusuf akan diperiksa. February22, 2016. Diperoleh dari http://news.metrotvnews.com

2. Andre, B., Sjovold, E., Rannestad, T., \& Ringdal, G. (2014). The impact of work culture on quality of care in nursing homes - a review study. Scandinavian Journal of Caring Science, 28, 449-457. http://doi.org/10.1111/scs.12086

3. Eggenberger, T. L., Keller, K. B., Chase, S. K., \& Payne, L. (2012). A quantitative approach to evaluating caring in nursing simulation. Teaching with Technology, 33 (6),406-409. October 3, 2015. Diperoleh dari www.proquest.com

4. Farianita, R. (2016). Faktor-faktor yang berhubungan dengan kepuasan peserta BPJS terhadap pelayanan instalasi rawat jalan di rumah sakit tk.. III bhakti wira tamtama semarang. Skripsi: Universitas Negeri Semarang. Diperoleh dari: http://lib.unnes.ac.id/

5. Fatmawati, E. (2014). Gambaran faktor 
kinerja perawat dalam mendokumentasikan asuhan keperawatan di RSUD syekh yusuf gowa tahun 2014. (Abstrak skripsi tidak dipublikasikan). Universitas Hasanuddin, Makassar. February19, 2016. Diperoleh dari: http://repository.unhas.ac.id

6. Foster, G. M., \& Anderson, B. G. (2006). Antropologi kesehatan. (Priyanti Pakan Suryadarma\&Meutia F. Hatta Swasono, Penerjemah). Jakarta: UI Press.

7. Gurusinga, R., Sulistyaningsih, W., \& Tarigan, M. (2013). Perilaku caring perawat dan kepuasan pasien rawat inap. Indonesian Nursing Research Journal, 1(2),150-155. October 3, 2015. Diperoleh dari: http://medistra.ac.id

8. Hafid, A. (2014). Hubungan kinerja perawat terhadap tingkat kepuasan pasien penggunan yankestis dalam pelayanan keperawatan di RSUD syech yusuf gowa. Jurnal Kesehatan, 7(2), 368-375. February19, $2016 . \quad$ Diperoleh dari: http://download.portalgaruda.org

9. Hamdat, S. (2010). Budaya pangan dan gaya hidup keluarga makassar: dalam perspektif antropologis. Makassar: ASPublishing.

10. Hariyati, R.T.S. (2014). Perencanaan, pengembangan, dan utilisasi tenaga keperawatan. Depok: PT Rajagrafindo Persada.

11. Joint Commission International (JCI). (2014). Joint commission international accreditation standards for hospitals, 5th edition.

12. Junaidi, Saleh, A., \& Budu. (2014). Efek bimbingan fungsi manajemen terhadap pelaksanaan fungsi manajerial kepala ruangan di RSKD provinsi sulawesi selatan (Tesis tidak dipublikasikan). Tesis: Universitas Hasanuddin. July 13, 2016. Diperoleh dari: http://pasca.unhas.ac.id/

13. Kabar Gowa. (24 Februari 2016). Kementerian kesehatan bicara kasus kusta di gowa. February19, 2016. Diperoleh dari: http://kabargowa.com

14. Kementerian Dalam Negeri (Kemendagri) RI. (2013).Kabupaten gowa. February19, $2016 . \quad$ Diperoleh dari: http://www.kemendagri.go.id

15. Kepmenkes RI No. 129 tahun 2008 tentang standard pelayanan minimal rumah sakit.

16. Kepmenkes RI No. 856 tahun 2009 tentang standard Instalasi Gawat Darurat (IGD).

17. Komisi Akreditasi Rumah Sakit. (2012). Instrumen akreditasi rumah sakit standar akreditasi versi 2012. Jakarta.

18. Kuswarno, E. (2006). Tradisi fenomenologi pada penelitian komunikasi kualitatif: sebuah pengalaman akademis. Mediator, 7 (1), 47-58.

19. Liliskarlina \& Ekawaty, D. (2018). Analisis implementasi jaminan kesehatan nasional di Kabupaten Gowa. Patria Artha Journal of Nursing Science. 2 (2). 119-128. DOI: http://dx.doi.org/10.33857\%2Fjns.v2i2.158

20. Marquis, B.L., \& Huston,C.J. (2012). Leadership roles and management functions in $\quad$ nursing $\left(7^{\text {th }} \quad\right.$ edition).Philadelphia: Lippincott Williams and Wilkins.

21. Mulyana, A.,S., Tanrewali, M.,S., \& Muhlis, I. (2018). Intervensi spiritual care dalam menangani kecemasan keluarga penderita kanker. Patria Artha Journal of Nursing Science, 2 (2), 73-80. DOI: http://dx/doi.org/10.3788\%2F184.

22. Muninjaya, G. (2004). Manajemen kesehatan, ed.2. Jakarta: Penerbit Buku Kedokteran EGC.

23. Nurmin, W. (29 November 2015). RSUD syekh yusuf gowa tolak pasien gegara listrik padam. February 22, 2016. Diperoleh dari: http://makassar.tribunnews.com

24. Nurmin, W. (23 Februari 2016). 114 kasus, kusta jadi penyakit terbesar kedua di gowa.February26, 2016. Diperoleh dari: http://makassar.tribunnews.com

25. Nursalam. (18 Januari 2014). Caring sebagai dasar peningkatan mutu pelayanan keperawatan dan keselamatan pasien. January 18, 2016. Diperoleh dari: http://ners.unair.ac.id

26. Nursalam. (2015). Manajemen keperawatan: aplikasi dalam praktik keperawatan profesional. Jakarta: Penerbit Salemba Medika.

27. Paldanius, A.,\& Maatta, K. (2011). What are student's views of (loving) caring in nursing education in finland?. International Journal of Caring Sciences, 4. 81-89. October 3, 2015. Diperoleh dari: www.proquest.com. 
28. Polit, D. F., \& Hungler, B. P. (1999). Nursing research: principle and methods. Philadelphia: Lippincott Williams \& Wilkins.

29. Polit, D. F., \&Beck, C. T. (2010). Essentials of nursing research: appraising evidence for nursing practice. 7th edition. Philadelphia: Lippincott Williams \& Wilkins.

30. Pope, C., Royen, P. V., \& Baker, R. (2013). Qualitative methods in research on healthcare quality. Quality Improvement Research, 11(13), 148-152. Diperoleh dari: www.qualityhealthcare.com.

31. Rahman, D. A. (2015). Gambaran mutu pelayanan kesehatan peserta bpjs di instalasi rawat jalan rsud syekh yusuf kabupaten gowa tahun 2015.February22, 2016. February19, 2016. Abstrak diperoleh dari: http://repository.unhas.ac.id

32. RSUD Syech Yusup Gowa. (2015). Profil RSUD syech yusup gowa.February22, 2016.Dikutip dari: http://rumahsakit.findthebest.co.id

33. Ribeiro, C., T., S. (2015). Pengaruh pelayanan, harga, dan fasilitas terhadap kepuasan pasien (Skripsi tidak dipublikasikan). June 24, 2016. Diperoleh dari: http://eprints.upnjatim.ac.id/

34. Sahertian, D. (2015). Gambaran kepuasan pasien umum instalasi rawat jalan di rumah sakit universitas hasanuddin makassar tahun 2015. (Abstrak). February19, 2016. Diperoleh dari:http://repository.unhas.ac.id

35. Sar-Ril. (2015, November 17). RSUD Syech yusuf gowa raih akreditasi penuh.Berita Kota Makassar.Diperoleh dari: http://beritakotamakassar.com/2015/11/17/r sud-syekh-yusuf-gowa-raih-akreditasipenuh/

36. Sitorus, R., \& Panjaitan, R. (2011). Manajemen keperawatan: manajemen keperawatan di ruang rawat. Jakarta: Sagung Seto.

37. Stein, J., \& Parbury. (2006). Patient and person: interpersonal skills in nursing. Australia: Elseiver.

38. Suaib, Indar, \& Jafar, N. (2012). Pengaruh kualitas pelayanan terhadap kepuasan pasien di ruang rawat inap rsud syekh yusuf kabupaten gowa. February19, 2016.
Diperoleh dari:http://pasca.unhas.ac.id

39. Surianti. (2014). Faktor yang mempengaruhi kepuasan pasien di ruang rawat inap rumah sakit umum daerah polewali tahun 2012 (Abstrak skripsi). February19, 2016. Diperoleh dari: http://repository.unhas.ac.id

40. Tscudin, V. (2007). Ethics in nursing: the caring relationship. USA: Elsevier.

41. Undang-Undang Republik Indonesia Nomor 38 tahun 2014 tentang Keperawatan.

42. Wangge, A. L. W. (2013). Gambaran kepuasan pasien umum tentang kualitas pelayanan pada instalasi rawat inap rsud daya makassar tahun 2013. (Abstrak). February 19, 2016. Diperoleh dari: http://repository.unhas.ac.id

43. Watson, J. (2007). Watson's Theory of Human Caring and Subjective Living Experiences: Carative Factors/ Caritas Processes as A Disciplinary Guide to The Professional Nursing Practice. Texto ContextoEnferm, Flori Anopolis. 16 (1). 129-135. Diperoleh dari: http://www.scielo.br/pdf/tce/v16n1/a16v16n 1. pdf

44. Watson, J. (2009). Caring as the essence and science of nursing and healthcare. Mundo Da Saude Sao Paulo, 33(2),143-149. February24, 2016. Diperoleh dari: http://saocamilosp.br/pdf/mundo_saude/67/143a149.pdf

45. Wibowo, A. (2014). Metodologi penelitian praktis bidang kesehatan. Depok: Rajawali Pers 
JOURNAL OF ISLAMIC NURSING 